\title{
Mineralogical stabilization of Ternesite in Belite Sulfo-Aluminate Clinker elaborated from limestone, shale and phosphogypsum
}

\author{
K. BEN ADDI ${ }^{1}$, A. DIOURI ${ }^{1}$, N. KHACHANI ${ }^{1}$, A. BOUKHARI ${ }^{1}$ \\ ${ }^{1}$ Laboratory of Applied Solid State Chemistry, Faculty of science, University Mohammed V-Rabat, Morocco \\ *Corresponding authors: khadijabenaddii@gmail.com, abdeljebbar.diouri@gmail.com
}

\begin{abstract}
This paper investigates the mineralogical evolution of sulfoaluminate clinker elaborated from moroccan prime materials limestone, shale and phosphogypsum as a byproduct from phosphoric acid factories. The advantage of the production of this type of clinker is related to the low clinkerisation temperature which is known around $1250^{\circ} \mathrm{C}$, and to less consumption quantity of limestone thus enabling less $\mathrm{CO}_{2}$ emissions during the decarbonation process compared to that of Portland cement. In this study we determine the stability conditions of belite sulfoaluminate clinker containing belite $\left(C_{2} S\right)$ ye'elimite $\left(C_{4} A_{3} \$\right)$ and ternesite $\left(C_{5} S_{2} \$\right)$. The hydration compounds of this clinker are also investigated. The monitoring of the synthesized and hydrated phases is performed by X-Ray Diffraction and Infrared spectroscopy. The results show the formation of ternesite at $800^{\circ} \mathrm{C}$ and the stabilization of clinker containing y'elminite, belite and ternesite at temperatures between 1100 and $1250^{\circ} \mathrm{C}$.
\end{abstract}

\section{Introduction}

The literature relating to sulfo-aluminate cement is abundant, but remains much less vast than that dealing with Portland cement. Sulfo-aluminate cements are relatively recent hydraulic binders, these cements are still little known differently than by specialists. They present unquestionable assets and many potential applications. Moreover, the ecological advantages of these cements also arouse the interest of the researchers. Its use thus seems an alternative of choice allowing the reduction of gas emissions for greenhouse effects, and constitutes one of the replacement solutions partial or total Portland cement for some applications.

The production of sulfo-aluminate cements indeed has two advantages compared to that of Portland cement: on the one hand, the temperature of firing is less high (approximately $1250^{\circ} \mathrm{C}$ ) and on the other hand, the manufacturing of this cement requires the consumption of a less quantity of limestone, which reduces the $\mathrm{CO}_{2}$ emissions during the decarbonation process, compared with that of Portland cement, the manufacturing of sulfoaluminate cement makes it possible to reduce of almost $35 \%$ the carbon dioxide emissions [1]. Energy efficiency is also improved, as the lower burning temperature reduces fuel consumption by roughly $10 \%$ [1]. But knowledge on the properties related to its modified chemical and mineralogical composition are less varied and requires advantage research to better understand of the mechanisms, temperatures and phase transformation stages in these cements.

The manufacturing of sulfo-aluminate cement is carried out from a source of aluminuim like bauxite $(40 \%)$ and of a source of sulphate $(20 \%)$ [2]. The obtained sulfo-aluminate clinker is mainly composed of ye'elimite $\left(\mathrm{C}_{4} \mathrm{~A}_{3} \$ \approx 65 \%\right)$, of bellite $\left(\mathrm{C}_{2} \mathrm{~S} \approx 20 \%\right)$ (cement notation used throughout the document: $\mathrm{A}=\mathrm{Al} 2 \mathrm{O} 3, \mathrm{C}=\mathrm{CaO}, \mathrm{F}=$ $\mathrm{Fe}_{2} \mathrm{O}_{3}, \mathrm{H}=\mathrm{H}_{2} \mathrm{O}, \mathrm{K}=\mathrm{K}_{2} \mathrm{O}, \mathrm{M}=\mathrm{MgO}, \mathrm{S}=\mathrm{SiO}_{2}, \mathrm{~T}=\mathrm{TiO}_{2}$, $\$=\mathrm{SO}_{3}$ ).

The formation of solid solutions of $\mathrm{C}_{4} \mathrm{~A}_{3} \$$ is hindered by rich concentrations of additives, mainly due to the phosphorus effect that enlarges the stability field of the calcium aluminate phases at the expense of the calcium sulfoaluminate field. My.Y. Benarchid et al. [3] showed that the presence of the $\mathrm{Cr}_{2} \mathrm{O}_{3}$ and $\mathrm{P}_{2} \mathrm{O}_{5}$ oxides lowered the decomposition of $\mathrm{CaCO}_{3}$. The enthalpy of decarbonation and the enthalpy of the formation of the solid solutions based on tricalcium aluminate formation decreased when the concentrations of additives increased. In another study [4] the authors showed that the maximum of the initial heat rate of the hydration process of $\mathrm{C}_{4} \mathrm{~A}_{3} \$$ decreases with an increase in the concentration of $\mathrm{Cr}_{2} \mathrm{O}_{3}$ and $\mathrm{P}_{2} \mathrm{O}_{5}$ oxides. The incorporation of these oxides in the crystal lattice of $\mathrm{C}_{4} \mathrm{~A}_{3} \$$ induces a long 
induction period during the hydration reaction and the principal products of hydration are ettringite, calcium monosulfate and gibsite.

The calcium sulfoaluminate phase, also named as Ye'elimite $\left(\mathrm{C}_{4} \mathrm{~A}_{3} \$\right)$, has been known as hydraulic phase for several decades, but its potential in non-expansive cementitious materials has only recently been reported.

As a result of many researches [5], an optimized formulation based on a clinker containing $\mathrm{C}_{4} \mathrm{~A}_{3} \$$, belite $\left(\mathrm{C}_{2} \mathrm{~S}\right)$ and Ternesite $\left(\mathrm{C}_{5} \mathrm{~S}_{2} \$\right)$ was developed [6]. As a consequence, the clinkerization temperature of this type of cement is low $\left(1200^{\circ} \mathrm{C}\right)$ compared to Ordinary Portland Cement $\left(1400-1450^{\circ} \mathrm{C}\right)$. It is thus currently attracting a great deal of interest worldwide [7, 8]. Its advantages include: i) reduced energy consumption during manufacturing, ii) low $\mathrm{CO}_{2}$ emission during manufacturing [9], iii) acceptable setting times and highearly strength development, [10], iv) very good durability, particularly in marine constructions [11].

The ternesite phase $\mathrm{C}_{5} \mathrm{~S}_{2} \$$ is a calcium sulphosilicate known also as sulphospurrite, its formation is based on the presence of belite and anhydrite [6] according to the formula (1)

$$
2 \mathrm{C}_{2} \mathrm{~S}+\mathrm{CS} \longrightarrow \mathrm{C}_{5} \mathrm{~S}_{2} \mathrm{~S}
$$

When ternesite is formed or stabilised at temperatures above $1200{ }^{\circ} \mathrm{C}$, the use of a mineralizer such as phosphates or fluorides is required. Another possibility to form ternesite is a methodology, developed by Frank Bullerjahn and Al. [6], which is based upon a two-step clinkering procedure. In a first step, the clinker is sintered at a temperature of at least $1250{ }^{\circ} \mathrm{C}$. In a second step, a slow cooling or so called "second clinkering" is applied by decreasing the temperature from 1200 to $800{ }^{\circ} \mathrm{C}$.

Accordingly, the production of supposed ternesite belite calcium sulpho-aluminate ferrite clinkers offers facilitate potential for the beneficiation and the advancement of clinkers and bonds in view of calcium sulpho-aluminate. These clinker sorts could be produced utilizing a comparable process to belite calcium sulphoaluminate clinkers, however inside a temperature scope of 900 to $1300^{\circ} \mathrm{C}$.

\section{Materials and methods}

\subsection{Mixture}

The raw materials used in this study are: limestone, shale, and phosphogypsum. The chemical compositions determined by XRF are given in Table 1 . In order to prepare the basic raw mixture, all of the raw materials are homogenized during 4 minutes in a disc crusher. The final mixtures were homogenized manually by using one ceramics mortar, a rammer and ethanol as a dispersive media to improve homogeneity of sample.
Table 1: Chemical composition of raw materials (Wt \%)

\begin{tabular}{|l|c|c|c|}
\cline { 2 - 4 } \multicolumn{1}{c|}{} & Limestone & Shale & Phosphogypsum \\
\hline $\mathbf{C a O}$ & 50,81 & 5,05 & 30,45 \\
\hline $\mathbf{S i O}_{\mathbf{2}}$ & 7,67 & 35,34 & 9,50 \\
\hline $\mathbf{A l}_{\mathbf{2}} \mathbf{O}_{\mathbf{3}}$ & 2,41 & 14,21 & 2,80 \\
\hline $\mathbf{F e}_{\mathbf{2}} \mathbf{O}_{\mathbf{3}}$ & 1,15 & 5,23 & 0,90 \\
\hline $\mathbf{S O}_{\mathbf{3}}$ & 0,26 & 0,15 & 42,9 \\
\hline $\mathbf{M g O}$ & 0,57 & 1,88 & 0,30 \\
\hline $\mathbf{K}_{\mathbf{2}} \mathbf{O}$ & 0,16 & 0,30 & 0,10 \\
\hline $\mathbf{P}_{\mathbf{2}} \mathbf{O}_{\mathbf{5}}$ & 0,29 & 0,11 & 0,63 \\
\hline $\mathbf{L O I}$ & 36,68 & 37,73 & 12,42 \\
\hline
\end{tabular}

The basic mixture made by the starting materials was carried out by a first approximation calculating raw believed to have a clinker at an approximate mineralogical composition wherein the produced phases would be within the average values of : $50 \%$ of belite $\left(\mathrm{C}_{2} \mathrm{~S}\right), 30 \%$ of ye'elimite $\left(\mathrm{C}_{4} \mathrm{~A}_{3} \$\right)$ and $20 \%$ of ternisite $\left(\mathrm{C}_{5} \mathrm{~S}_{2} \$\right)$. The calculation is based, at a first approximation, on the quantitative distribution of the oxides $\mathrm{CaO}, \mathrm{SiO}_{2}, \mathrm{Al}_{2} \mathrm{O}_{3}$ and $\mathrm{SO}_{3}$ of starting materials in the $\mathrm{C}_{2} \mathrm{~S}, \mathrm{C}_{4} \mathrm{~A}_{3} \$$ and $\mathrm{C}_{5} \mathrm{~S}_{2} \$$ phases planned in the target clinker. Determining the composition of the mixture to achieve, from the chemical composition of raw materials, gives the intended composition shown in Table 2.

The clinkering of the samples were carried out in platinum crucible in a laboratory furnace at different temperatures: $800^{\circ} \mathrm{C}(24 \mathrm{~h}), 1000^{\circ} \mathrm{C}(12 \mathrm{~h}), 1100^{\circ} \mathrm{C}(12 \mathrm{~h})$, and $1250^{\circ} \mathrm{C}(6 \mathrm{~h})$, with an intermediate crushing in order to increase the homogeneity. The mineralogical evolutions of the various elaborated clinkers and their pastes are carried out using XR-Diffraction and IR spectroscopy. To do this, the hydrated samples were crushed, immersed in ethanol to stop the hydration and then dried in an oven set. In order to investigate the hydraulic behavior of sulfo-aluminate belite clinker, the synthesized clinkers were hydrated for up to 90 days at ambient temperature with the w/c $=0.5$.

Table 2: Anticipated composition of raw basic mixture

\begin{tabular}{|c|c|c|c|}
\cline { 2 - 4 } \multicolumn{1}{c|}{} & Limestone & shale & Phosphogypsum \\
\hline $\mathrm{Wt} \%$ & 55.04 & 37.42 & 7.54 \\
\hline
\end{tabular}

\subsection{Characterization}

X-ray Fluorescence (XRF) is a widely used technique for both qualitative and quantitative elemental analysis of solids, powders. The pearls were prepared by adding $5 \mathrm{~g}$ of lithium titraborate (melted) to $1 \mathrm{~g}$ of crushed and grounded powder, the homogenized mixture was placed into a Platinum crucible and brought up to the complete melting until pearl level; the melt is poured into the mold and cooled up until the pearl detached from the mold. 
X-ray diffraction analysis is performed in order to examine the mineralogical composition of the samples. The diagrams were collected using a Siemens D 500 Powder diffractometer equipped with a copper anticathode $(\mathrm{CuK}=1.5418 \AA)$ at scanning speed of $0.04^{\circ}$.s- 1 from 10 to $60^{\circ}$.

The Infra-red Spectroscopy with Transform of Fourier (or FTIR: Fourier Transform Infra-Red Spectroscopy) is based on the infra-red absorption of radiation by analyzed material. The absorbed frequencies by molecular vibration are ranging between 4000 and $400 \mathrm{~cm}-1$. The used abbreviation to describe studied samples is detailed in Table 3

Table 3: Designation of burned and hydrated samples

\begin{tabular}{|c|c|c|c|c|}
\hline $\begin{array}{c}\text { Burned Sample } \\
\text { designation }\end{array}$ & CSA1 & CSA2 & CSA3 & CSA4 \\
\hline $\begin{array}{c}\text { Burning } \\
\text { température }\left({ }^{\circ} \mathrm{C}\right)\end{array}$ & 800 & 1000 & 1100 & 1250 \\
\hline $\begin{array}{c}\text { Hydrated Sample } \\
\text { designation }\end{array}$ & CSA5 & CSA6 & CSA7 & CSA8 \\
\hline $\begin{array}{c}\text { Hydration time } \\
\text { (Days) }\end{array}$ & 2 & 7 & 28 & 90 \\
\hline
\end{tabular}

\section{3 Results and discussion}

\subsection{Elaboration and characterization of belite sulfo-aluminate clinker}

Different phases are identified by X-ray diffraction for the anhydrous samples CSA1-CSA4. The spectra are presented in figure 1 and their percentages are respectively collected in table 4 . These results are obtained by applying the Rietveld method for the determination of semi-quantitative proportions of present phases at each temperature. The observed mineralogy of the synthesized clinker, applying the sintering process described above, displays a composition close to that expected, showing a tendency to form a $\beta-\mathrm{C}_{2} \mathrm{~S}$ polymorph of dicalcium silicate as a main formed phase observed at $2 \theta=32,50^{\circ}[12,13]$, while $\mathrm{C}_{4} \mathrm{~A}_{3} \$$ is present in orthorhombic and cubic forms. Bullerjahn Frank et al. found the same phases using calcite powder, siliceous fly ash, and natural anhydrite as starting materials [6].

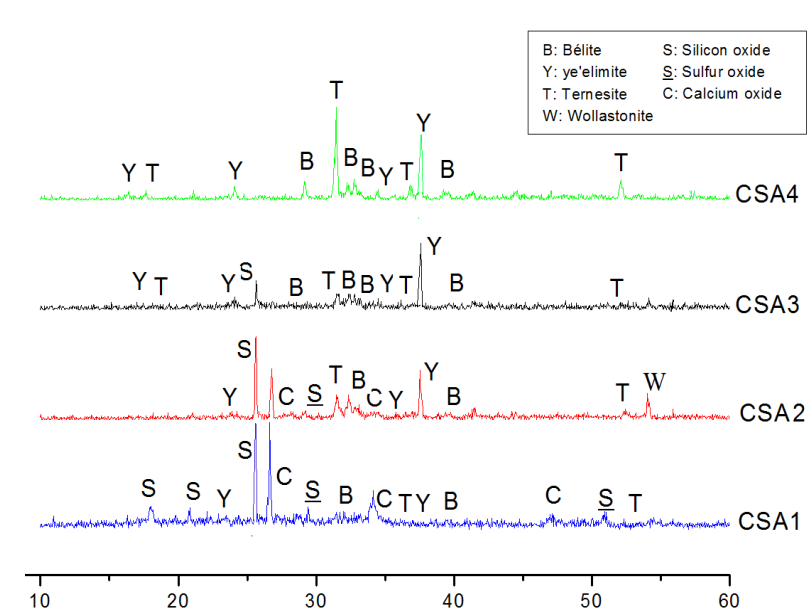

Figure 1: X-ray diffraction spectra of the synthesized clinker CSA1-CSA4

The decomposition of limestone is observed at $800^{\circ} \mathrm{C}$, lower temperature compared to those typically known for this reaction $\left(860^{\circ} \mathrm{C}\right)$, this result was also observed by $\mathrm{Y}$. WANG et al. [14]. Comparing the amounts of the formed phases during clinkerization we observe that increasing the temperature above $1000^{\circ} \mathrm{C}$ leads to the reduction and cancellation of the amounts of $\mathrm{CaO}$ and $\mathrm{SiO}_{2}$ and formation of the intermediate phase $\mathrm{CaSiO}_{3}$ between 1000 and $1100^{\circ} \mathrm{C}$ according to the reaction (2).

$$
\mathrm{CaO}+\mathrm{SiO}_{2} \rightarrow \mathrm{CaO} \cdot \mathrm{SiO}_{2}(\mathrm{CS})
$$

Then, the percentage of $\mathrm{C}_{2} \mathrm{~S}$ grows beyond $1100^{\circ} \mathrm{C}$ according to the reaction (3) [15].

$$
\mathrm{CaO} \cdot \mathrm{SiO}_{2}+\mathrm{CaO} \rightarrow 2 \mathrm{CaO} \cdot \mathrm{SiO}_{2}\left(\mathrm{C}_{2} \mathrm{~S}\right)
$$

Table 4: Semi-quantitative identification of mineral phases in synthesized clinker CSA1-CSA4

\begin{tabular}{|l|c|c|c|c|}
\cline { 2 - 5 } \multicolumn{1}{c|}{} & CSA1 & CSA2 & CSA3 & CSA4 \\
\hline $\mathbf{C}_{\mathbf{2}} \mathbf{S}$ & 11,51 & 53,09 & 49,01 & 52,92 \\
\hline $\mathbf{C}_{\mathbf{4}} \mathbf{A}_{\mathbf{3}} \mathbf{\$}$ & 15,85 & 22,02 & 24,96 & 28,09 \\
\hline $\mathbf{C}_{\mathbf{5}} \mathbf{S}_{\mathbf{2}} \mathbf{5}$ & 12,60 & 17,80 & 18,45 & 18,90 \\
\hline $\mathbf{C S}$ & - & 7,47 & 0,08 & - \\
\hline $\mathbf{C a O}$ & 37,76 & 1,06 & - & - \\
\hline $\mathbf{S i O}$ & 13,70 & 2,05 & - & - \\
\hline $\mathbf{S O}_{\mathbf{3}}$ & 8,5 & 3,01 & - & - \\
\hline
\end{tabular}

The three phases $\mathrm{C}_{2} \mathrm{~S}, \mathrm{C}_{4} \mathrm{~A}_{3} \$$ and $\mathrm{C}_{5} \mathrm{~S}_{2} \$$ form in small amounts from the temperature of $800^{\circ} \mathrm{C}$, their quantities increase until the order of $53 \%$ for $\mathrm{C} 2 \mathrm{~S}, 28 \%$ for $\mathrm{C}_{4} \mathrm{~A}_{3} \$$ and not exceed 18 to $20 \%$ for the ternesite phase, during all the treatment process up to $1250^{\circ} \mathrm{C}$. It appears clearly that beyond the temperature of $1100^{\circ} \mathrm{C}$, there is a joint stability of the three phases $\mathrm{C}_{2} \mathrm{~S}, \mathrm{C}_{4} \mathrm{~A}_{3} \$$ and $\mathrm{C}_{5} \mathrm{~S}_{2} \$$, this result is of agreement with the many previous published results $[6,16-20]$. The appropriate burning condition of 
pure ternesite, is found to be $1200^{\circ} \mathrm{C}$ for $8 \mathrm{~h}$. The secondary heat treatment between 1100 and $1250^{\circ} \mathrm{C}$ can significantly promote the formation of ternesite from the reaction of belite and anhydrite in sulfo-aluminate clinkers[18]. The increase of the $\mathrm{SO}_{3}$ content in the raw meal leads to the replacement of large amounts of $\mathrm{C}_{2} \mathrm{~S}$ by ternesite, which is stable in the temperature ranging between 900 and $1250^{\circ} \mathrm{C}$ [6].

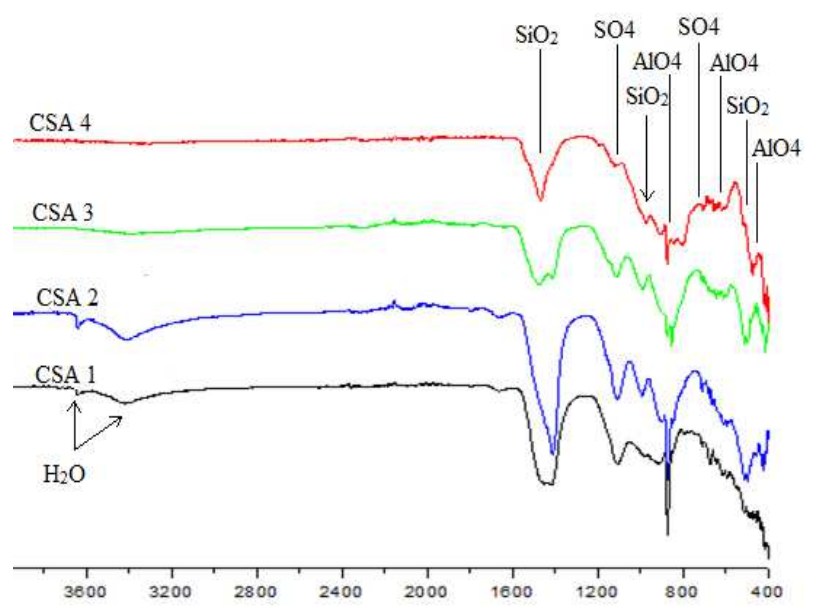

Figure 2: Infrared spectra of CSA1- CSA4 sample

The ternesite phase formed as a second major phase instead of $\mathrm{C}_{2} \mathrm{~S}$ and $\mathrm{CS}$, in addition to $\mathrm{C}_{4} \mathrm{~A}_{3} \$$. Upon hydration, this cement produced very high mechanical strength at early and later ages [20].

The infrared absorption spectra of CSA1-CSA4 samples reported in figure 2 and table 5 showed that the major absorption bands of the clinker phases are in the region 1600 to $400 \mathrm{~cm}-1$. The main vibration bands of the different groups are listed in Table 5. The Si-O2 stretching mode produces an absorption band at 991,879, and $847 \mathrm{~cm}-1$ in $\mathrm{C}_{2} \mathrm{~S}$ [21], while a broader band with peaks observed at 500 and $1000 \mathrm{~cm}-1$ is assigned to the same stretching mode in $\mathrm{C}_{5} \mathrm{~S}_{2} \$$. The $\mathrm{SO} 4$ groups are identified at $610,613,620 \mathrm{~cm}-1$ in $\mathrm{C}_{4} \mathrm{~A}_{3} \$[22,23]$, while bands with peaks observed at 1100 and $1150 \mathrm{~cm}-1$ are assigned to this vibration in $\mathrm{C}_{5} \mathrm{~S}_{2} \$$. The $\mathrm{AlO} 4$ groups vibration identified at 420, 600, and $870 \mathrm{~cm}-1$ are assigned to $\mathrm{C} 4 \mathrm{~A} 3 \$$ phase.

Table 5: Major vibration bands observed by IR spectroscopy in CSA1- CSA4 samples

\begin{tabular}{|c|c|c|c|c|}
\hline & CSA1 & CSA2 & CSA3 & CSA4 \\
\hline${\text { Group } \mathrm{SiO}_{2}}$ & $1000 \mathrm{f}$ & $1000 \mathrm{M}$ & $1000 \mathrm{M}$ & $991 \mathrm{f}$ \\
\hline Group $\mathrm{SiO}_{2}$ & $879 \mathrm{f}$ & $879 \mathrm{f}$ & $847 \mathrm{f}$ & $847 \mathrm{f}$ \\
\hline${\text { Group } \mathrm{SiO}_{2}}$ & $500 \mathrm{~F}$ & $500 \mathrm{M}$ & $500 \mathrm{M}$ & $500 \mathrm{~F}$ \\
\hline $\begin{array}{l}\text { Group } \\
\mathrm{AlO}_{4}\end{array}$ & $420 \mathrm{f}$ & $420 \mathrm{M}$ & $420 \mathrm{M}$ & $420 \mathrm{f}$ \\
\hline $\begin{array}{l}\text { Group } \\
\mathrm{AlO}_{4}\end{array}$ & $600 \mathrm{f}$ & $600 \mathrm{f}$ & $600 \mathrm{f}$ & $600 \mathrm{f}$ \\
\hline $\begin{array}{l}\text { Group } \\
\mathrm{AlO}_{4}\end{array}$ & $870 \mathrm{~F}$ & $870 \mathrm{~F}$ & $870 \mathrm{M}$ & $870 \mathrm{M}$ \\
\hline Group SO$_{4}$ & $610 \mathrm{f}$ & $613 \mathrm{f}$ & $615 \mathrm{f}$ & $620 \mathrm{f}$ \\
\hline${\text { Group } \mathrm{SO}_{4}}$ & $1100 \mathrm{M}$ & $1100 \mathrm{M}$ & $1150 \mathrm{f}$ & $1150 \mathrm{f}$ \\
\hline Group $\mathrm{H}_{2} \mathrm{O}$ & $3620 \mathrm{f}$ & $3620 \mathrm{f}$ & & \\
\hline Group $\mathrm{H}_{2} \mathrm{O}$ & $3400 \mathrm{f}$ & $3400 \mathrm{f}$ & & \\
\hline
\end{tabular}

\begin{tabular}{|l|l|l|l|l|}
\hline $\begin{array}{l}\text { Group } \\
\text { CaO }\end{array}$ & $1400 \mathrm{~F}$ & $1400 \mathrm{~F}$ & $1450 \mathrm{~F}$ & $1450 \mathrm{~F}$ \\
\hline
\end{tabular}

\subsection{Hydration}

The hydrated samples CSA5-CSA8 of the cement pastes has been investigated at 2 days, 7days, 28 days, and 90 days. XRD technique showed the formation of hydration product of ye'elimite, the ettringite phase characterized by the diffraction peaks of maximum intensities observed at $2 \theta=9,65$ (Figure 3 and Table 6 ) according to the reaction (4).

$$
\mathrm{C}_{4} \mathrm{~A}_{3} \$+2 \mathrm{C} \$+38 \mathrm{H} \rightarrow \mathrm{C}_{3} \mathrm{~A} .3 \mathrm{C} \$ .32 \mathrm{H}+2 \mathrm{AH}_{3}
$$

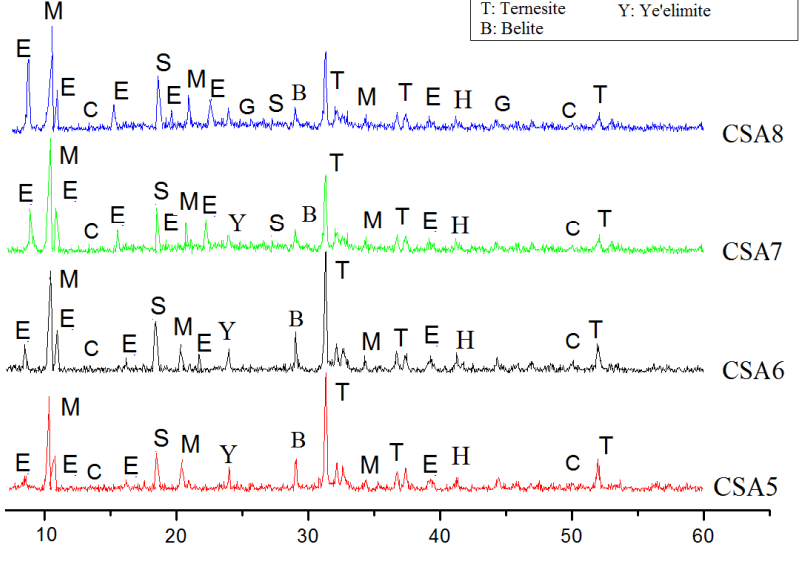

Figure 3: X-ray diffraction spectra of the hydrated samples CSA5-CSA8

The diffraction peaks relating to Gibbsite are identified at $2 \theta=44,82$ [15], and the peaks of monosulfate are detectable at $2 \theta=10,3$, indicating the partial decomposition of ettringite and its transformation into monosulfate. This result is agrees with previous published results $[18,24,25]$. The strätlingite, $\mathrm{C}_{2} \mathrm{ASH}_{3}$, is formed from the reaction of belite which consumes a portion of $\mathrm{AH} 3$ produced by hydration of ye'elimite according to the reaction (5)

$$
\mathrm{C}_{2} \mathrm{~S}+\mathrm{AH}_{3}+5 \mathrm{H} \rightarrow \mathrm{C}_{2} \mathrm{ASH}_{3}
$$

Table 6: Semi-quantitative identification of mineral phases in hydrated samples CSA5-CSA8

\begin{tabular}{|l|l|l|l|l|}
\cline { 2 - 5 } \multicolumn{1}{c|}{} & CSA5 & CSA6 & CSA7 & CSA8 \\
\hline Calcuim slicate $\mathbf{C}_{\mathbf{2}} \mathbf{S}$ & 8,68 & 4,43 & 1,93 & 0,53 \\
\hline Ye'elimite $\mathbf{C}_{\mathbf{4}} \mathbf{A}_{\mathbf{3}} \mathbf{\$}$ & 6,27 & 3,21 & 1,32 & 0,94 \\
\hline Ternesite $\mathbf{C}_{\mathbf{5}} \mathbf{S}_{\mathbf{2}} \mathbf{\$}$ & 17,22 & 17,17 & 17,02 & 7,85 \\
\hline Ettringite $\mathbf{C}_{\mathbf{6}} \mathbf{A} \mathbf{\$}_{\mathbf{3}} \mathbf{H}_{\mathbf{3 2}}$ & 22,36 & 28,54 & 29,93 & 39,34 \\
\hline $\begin{array}{l}\text { Monosulfoaluminate } \\
\mathbf{C}_{\mathbf{4}} \mathbf{A} \mathbf{\$ H _ { 1 2 }}\end{array}$ & 8,81 & 10,41 & 11,53 & 20,44 \\
\hline Gibbsite $\mathbf{A} \mathbf{H}_{\mathbf{3}}$ & 16,61 & 9,26 & 6,74 & 1,24 \\
\hline Strätlingite, $\mathbf{C}_{\mathbf{2}} \mathbf{A S H} \mathbf{S H}_{\mathbf{3}}$ & 11,45 & 19,56 & 24,43 & 24,65 \\
\hline
\end{tabular}




\begin{tabular}{|l|l|l|l|l|}
\hline Hexagonal hydrates & 4,47 & 4,43 & 4,34 & 3,95 \\
\hline Gypsum C\$H & 4,11 & 2,98 & 2,73 & 1,05 \\
\hline
\end{tabular}

The same results, deduced here, are obtained by Y.Shen and al.[18] which have shown that the pure ternesite can hydrate at a slow rate, and the addition of ye'elimite promotes the hydration of ternesite and the formation of ettringite. The ettringite formation for the clinker containing ternesite mainly depends on the dissolution of gypsum originating from the hydration of ternesite.

Figure 4 and table 7 shows the infrared spectra of the hydrated samples CSA5-CSA8, main infrared vibrations are summarized in Table 7. We identify the vibrations corresponding to the group $\left(\mathrm{SO}_{4}\right)$ in the ettringite $\mathrm{C}_{6} \mathrm{~A} \$_{3} \mathrm{H}_{32}$ at $1100 \mathrm{~cm}-1$ and in the monosulfoaluminate hydrated calcium $\mathrm{C}_{4} \mathrm{~A} \$ \mathrm{H}_{12}$ at 420,630 and $1000 \mathrm{~cm}-1$ like it has been shown by some authors [26, 27]. Absorption localized at $530 \mathrm{~cm}-1$ is due to binding of vibration $\left(\mathrm{AlO}_{6}\right)$ in the phase of ettringite, these results are the same obtained by M. Idrissi et al. [15]. on calcium sulfoaluminate phase elaborated by iron inclusion.

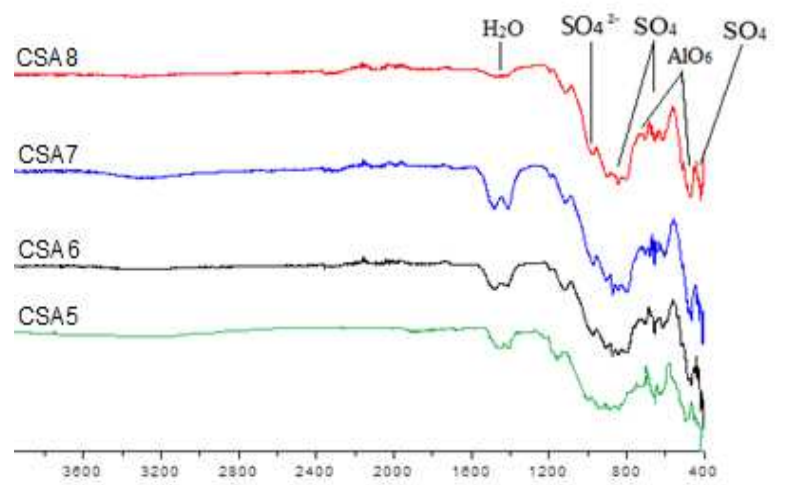

Figure 4: Infrared spectra of hydrated samples CSA5-CSA8

According to Table 6 we found that the percentage of increased ettringite in the sample CSA8 from $22 \%$ (at 2 days) to $39 \%$ (at 28 days), it may be due to the hydration of ternesite phases beyond 28 days, this result agrees with with previously mentioned results.

Previous studies reported that the ternesite is least reactive in pure ternesite system, the hydration of ternesite does not take place until 90 days, and gypsum has formed as new crystalline phase. The hydration process of ternesite starts by its partial dissolution, and after 28 days of hydration, only traces of ettringite are detectable while gypsum produced from the hydration of ternesite has almost been depleted [18], but in the presence of Yeelimite the ternesite hydration favors also the formation of gypsum and ettringite. [6].

Gallardo et al. [28] and Velazco et al. [29] were shown in the previously published results that the ettringite as the main hydration product although traces of monosuphate phase were also found. The addition of citric acid increased the setting time, modified the morphology of the ettringite needles, changed the microstructural configuration and prevented the decreasing in compressive strength of the samples caused by delayed ettringite formation, also Bazaldúa et al. [30] demonstrated that the main hydration products of supersulphated cements were C-S-H and Ettringite. These products precipitated since the first hours of hydration, forming a porous and weak microstructure; with time and up to one year, the C-S-H and Ettringite consolidated the microstructure and increased the compressive strength. The cements showed hydraulic behavior after curing under water.

Table 7: Major vibration bands observed by IR spectroscopy in

\begin{tabular}{|c|c|c|c|c|}
\hline \multicolumn{5}{|c|}{ CSA5-CSA8 samples } \\
\hline & CSA5 & CSA6 & CSA7 & CSA8 \\
\hline $\begin{array}{c}\mathrm{SO}_{4} \\
\text { corresponding to the } \\
\text { ettringite hydrated } \\
\text { calcium } \\
\text { monosulfoaluminate }\end{array}$ & $410 \mathrm{M}$ & $410 \mathrm{M}$ & $410 \mathrm{M}$ & $410 \mathrm{M}$ \\
\hline $\begin{array}{c}\mathrm{SO}_{4} \\
\text { corresponding to the } \\
\text { ettringite hydrated } \\
\text { calcium } \\
\text { monosulfoaluminate }\end{array}$ & $630 \mathrm{f}$ & $630 \mathrm{f}$ & $630 \mathrm{f}$ & $630 \mathrm{f}$ \\
\hline $\begin{array}{c}\mathrm{AlO}_{6} \\
\text { corresponding to the } \\
\text { ettringite and } \\
\text { strätlingite }\end{array}$ & $520 \mathrm{M}$ & $520 \mathrm{M}$ & $530 \mathrm{f}$ & $530 \mathrm{f}$ \\
\hline $\begin{array}{c}\mathrm{AlO}_{6} \text { corresponding } \\
\text { to hexagonal } \\
\text { hydrates }\end{array}$ & $780 \mathrm{M}$ & $780 \mathrm{M}$ & $770 \mathrm{f}$ & $770 \mathrm{f}$ \\
\hline $\begin{array}{l}\mathrm{SO}_{4}{ }^{2-} \\
\text { corresponding to the } \\
\text { ettringite }\end{array}$ & $1100 \mathrm{f}$ & $1100 \mathrm{f}$ & $1100 \mathrm{f}$ & $1100 \mathrm{f}$ \\
\hline $\mathrm{H} 2 \mathrm{O}$ & $\begin{array}{c}1580 \\
\mathrm{M} \\
\end{array}$ & $\begin{array}{c}1580 \\
M\end{array}$ & $1580 \mathrm{f}$ & $1580 \mathrm{f}$ \\
\hline
\end{tabular}

Frank Bullerjahn et all. [6] found that the $\mathrm{C}_{5} \mathrm{~S}_{2} \$$ phase in the clinker is more reactive than the $\mathrm{C}_{2} \mathrm{~S}$, unlike previous studies that considered the ternesite as an inert phase or showing a low reactivity [19, 31-35]. These studies conclude on the low reactivity of ternesite based on the chemical bound water and the low quantities of hydrates formed, which were present in trace amounts only. It has also been reported [36-37] that $\mathrm{C}_{5} \mathrm{~S}_{2} \$$ has better hydraulic properties after autoclaving, it transforms to a rapidly hardening and high strength compound [38]. Additionally, the hydration reaction of calcium sulphoaluminate initiates rapidly and forms ettringite and $\mathrm{AH}_{3}$ [39], contributing to faster setting of CSA cement than Portland cement [40].

All these results indicate that ternesite can be hydrated at a long-term, adding yeelimite not only induces hydration ternesite but also favors the formation of gypsum [6, 18], this gypsum in the pastes leads to ettringite formation and reduced the amount of formed monosulfoaluminate [40]. In this work we have clearly shown the formarion and joint stability at relatively moderate temperatures (1100$1250^{\circ} \mathrm{C}$ ) of the three phases $\mathrm{C}_{2} \mathrm{~S}, \mathrm{C}_{4} \mathrm{~A}_{3} \$$ and $\mathrm{C}_{5} \mathrm{~S}_{2} \$$. The hydration of this clinker shows the formation of usually known phases in relatively high proportions for Ettringite $\mathrm{C}_{6} \mathrm{~A} \$_{3} \mathrm{H}_{32}$ (22\%) from the second day and the formation 
of monosulfoaluminate $\mathrm{C}_{4} \mathrm{~A} \$ \mathrm{H}_{12}$ and strätlingite $\mathrm{C}_{2} \mathrm{ASH}_{3}$ in large amounts at 28 days.

\section{Conclusions}

The sulfoaluminate cements bring innovating technical solutions, those hydraulic materials find more uses in building and civil engineering by presenting a favorable ecological assessment. This work concerned the sulfoaluminate clinker characterized by the presence of $\mathrm{C}_{2} \mathrm{~S}$ (belite), $\mathrm{C}_{4} \mathrm{~A}_{3} \$$ (Ye'elimite) and of $\mathrm{C}_{5} \mathrm{~S}_{2} \$$ (ternesite). The clinker is elaborated by sintering raw materials at a temperature around $1100-1250^{\circ} \mathrm{C}$. The blended raw material is made up of a source of alumina (Shale), limestone and a source of sulphate calcium (phosphogypsum derived from phosphoric acid factories). The sulfoaluminate clinker is characterized by a carbonic reduction from approximately $35 \%$ due to the use of less limestone and lower clinkerisation temperature. The formation of ternesite is observed at least of $1100^{\circ} \mathrm{C}$, that is related to clinkering process. We observe also the stabilization of this phase at $1200^{\circ} \mathrm{C}$. The hydration process shows that all hydrate phases are formed in the first two days except the ternesite hydrated phase which takes place at later ages (beyond 28 days).

\section{References}

1. E. Gartner. Industrially interesting approaches to "lowCO2" cements, Cement and Concrete Research, 34, 1489-1498 (2004).

2. N. Fukuda. On the Constitution of Sulfo-Aluminous Clinker, Cement Division, 34 [1], 138-139 (1960) .

3. My.Y. Benarchid, A. Diouri, A. Boukhari, J. Aride, R. Castanet, J, Rogezc. Thermal study of chromiumphosphorus-doped tricalcium aluminate, Cement and Concrete Research, 31 [3], 449-454 (2001).

4. My.Y. Benarchid, J. Rogez, A. Diouri, A. Boukhari, J. Aride, Formation and hydraulic behavior of chromiumphosphorus doped calcium sulfoaluminate cement, Thermochimica Acta, 433, 183-186 (2005) .

5. W. Yanmou, S. Muzhen, Microstructural study of the interfacial zone between expansive sulphoaluminate cement pastes and limestone aggregates, Cement and Concrete Research, 26 [5], 805-812(1996).

6. F. Bullerjahn, D. Schmitt, M. Ben Haha, Effect of raw mix design and of clinkering process on the formation and mineralogical composition of (ternesite) belite calcium sulphoaluminate ferrite clinker, Cement and Concrete Research, 59, 87-95(2014).

7. K. Quillin. Performance of belite-sulfoaluminate cements, Cement Concrete Research, 31 [9], 13411349(2001).

8. R. J. Mangabhai, Calcium Aluminate Cement, E. \& F.N. SPON, London, (1990).

9. J.H. Sharp, C.D. Lawrence, R. Yang, Calcium sulfoaluminate cements-low-energy cements, special cements or what?, Advances in Cement Research. 11 [1], 3-13(1999).

10. Y. Wang, J. Deng, An investigation into cement CaO$\mathrm{SiO}_{2}-\mathrm{Al}_{2} \mathrm{O}_{3}-\mathrm{Fe}_{2} \mathrm{O}_{3}-\mathrm{SO}_{3}$ system, Proc. of the 8th Inter.
Congress on the Chemistry of Cement. Rio. De Janeiro., sub theme 1.3, 11, 300-305(1986).

11. FP. Glasser, L. Zhang, High-performance cement matrices based on calcium sulfoaluminate-belite composition. Cement and Concrete Research, 31 [12], 1881-1886(2001).

12. H.Y. Ghorab, M. Rizk, B. Ibrahim, M.M. Allam, High belite cement from alternative raw materials. Materiales de Construcción, 64 [314], e012 (2014).

13. A. Diouri, A. Boukhari, J. Aride, F. Puertas, T. Vázquez, Elaboration of $\alpha L^{\prime}-\mathrm{C} 2 \mathrm{~S}$ form of belite in phosphatic clinker, Study of hydraulic activity. Materiales de Construcción. 48 [249] (1998).

14. L. Zhang, M. Su, Y. Wang, Development of the use of sulfo- and ferroaluminate cements in China, Advances in Cement Research, 11 [1], 35-41 (1999).

15. M. Idrissi, A. Diouri, D. Damidot, J.M. Greneche, M. Alami Talbi, M. Taibi, Characterisation of iron inclusion during the formation of calcium sulfoaluminate phase, Cement and Concrete Research, 40 [8], 13141319(2010).

16. F.R.D. Andrade, S.D. Gomes, M. Pecchio, Y. Kihara, F.M.S. Carvalho, J.R. Matos, Effect of sulfur on the polymorphism and reactivity of dicalcium silicate of Portland clinker, Cerâmica, 57, 129-135 (2011).

17. B. Ziemer, B. Altrichter, Effect of $\mathrm{SO}_{3}$ on formation and hydraulic reactivity of belite, Cement and Concrete Research, 14 [5], 686-692 (1984).

18. Y. Shen, J. Qian, Y. Huang, D. Yang, Synthesis of belite sulfoaluminate-ternesite cements with phosphogypsum, Cement and Concrete Composites, 63, 67-75 (2015).

19. G. Belz, J. Beretka, M. Marrocoli, L. Santoro, N. Sherman, G.L. Valenti, Use of Fly Ash Blast Furnace Slag and Chemical Gypsum for the Synthesis of Calcium Sulfoaluminate-Based Cements, ACI materials journal, 153, 513-530 (1995).

20. N. Sherman, J. Beretka, L. Santoro, G.L, Valenti, Long-term behaviour of hydraulic binders based on calcium sulfoaluminate and calcium sulfosilicate, Cement and Concrete Research, 25, 113-126 (1995).

21. T.L. Hughes, C.M. Methven, T.G.J. Jones, S.E. Pelham, P. Fletcher, C. Hall, Determining Cement Composition by Fourier Transform Infrared Spectroscopy, Advanced Cement Based Materials, 2 [3], 91-104 (1995).

22. P. Zhang, Chen, L. Shi, G. Zhang, W. Huang, J. Wu, Proceedings of the Ninth, The 14th International Congress on the Chemistry of Cement, New Delhi, India. 3, 201-208 (1992).

23. X. Liu, Y. Li, N. Zhang, Influence of $\mathrm{MgO}$ on the formation of $\mathrm{Ca}_{3} \mathrm{SiO}_{5}$ and $3 \mathrm{CaO} \cdot 3 \mathrm{Al}_{2} \mathrm{O} 3 \cdot \mathrm{CaSO}_{4}$ minerals in alite sulphoaluminate cement, Cement and Concrete Research, 32 [7], 1125-1129 (2002).

24. B. Lothenbach, A. Nonat, Calcium silicate hydrates: Solid and liquid phase composition, Cement and Concrete Research, 78, 57-70 (2015).

25. S. Ioannou, L. Reig, K. Paine, K. Quillin, Properties of a ternary calcium sulfoaluminate- calcium sulfate-fly ash cement, Cement and Concrete Research, 56, 75-83 (2014). 
26. J. Bensted, S.P. Varma, Studies of ettringite and its derivatives, Cem. Technol, (1971).

27. R.B. Perkins, C.D. Palmer, Solubility of ettringite $\mathrm{Ca} 6(\mathrm{Al}(\mathrm{OH}) 6) 2\left(\mathrm{SO}_{4}\right)_{3} \cdot 26 \mathrm{H}_{2} \mathrm{O}$ at $5-75^{\circ} \mathrm{C}$. Geochim, Cosmochimca Acta, 63,1969-1980 (1999).

28. M. Gallardo, J.M. Almanza, D.A. Cortés, J.C. Escobedo, J.I. Escalante-García, Synthesis and mechanical properties of a calcium sulphoaluminate cement made of industrial wastes, Materiales de Construcción, 64 [315], e023 (2014).

29. G. Velazco, J.M. Almanza, D.A. Cortés, J.C. Escobedo, J.I, Escalante-Garcia Effect of citric acid and the hemihydrate amount on the properties of a calcium sulphoaluminate cement, Materiales de Construcción, 64 [316], e036 (2014).

30. Y. Shen, J. Qian, J. Chai, Y. Fan, Calcium sulphoaluminate cements made with phosphogypsum : Production issues and material properties, 48,67-74 (2014).

31. N. Sherman, J. Beretka, L. Santoro, G.L. Valenti, Long-term behaviour of hydraulic binders based on calcium sulfoaluminate and calcium sulfosilicate, Cement and Concrete Research, 25 [1], 113-126 (1995).

32. T.K. Tadzhiev, T.A. Atakuziev, F.K. Tadzhiev, Hardening of anhydrous calcium sulfoaluminate and sulfosilicate, UDC, 691 [54], 1434-1437 (1973).

33. M.Y. Benarchid, J. Rogez, A. Diouri, A. Boukhari, J. Aride, Formation and hydraulic behaviour of chromiumphosphorus doped calcium sulfoaluminate cement, Thermochimca Acta, 433 (1-2), 183-186 (2005).

34. V. Makhmudova, M. Iskandarova, Y. Ivanova, G. Chernev, N. Ruziev, Synthesis and properties of sulphoferrite calcium clinkers and low temperature cements on their basis, Journal of the University of Chemical Technology and Metallurgy, 46 [2], 151-154 (2011).

35. J. Beretka, M. Marrocoli, N. Sherman, G.L. Valenti, The influence of $\mathrm{C}_{4} \mathrm{~A}_{3} \mathrm{~S}$ content and WS ratio on the performance of calcium sulfoaluminate-based cements, Cement and Concrete Research, 26 [11], 1673-1681 (1996).

36. A.A. Pashchenko, Sulfate-containing Cements in 'New Cements', Kiev, Budivelnik, Russian, (1978).

37. T.K. Tadzhiev, T.A. Atakuziev, F.K. Tadzhiev, Investigation on the process of hardening of water free calcium sulphoaluminate and calcium sulphosilicate, Inorganic Materials, 9, 1634-1637 (1972).

38. N. Sherman, J. Beretka, L. G.L. Santoro Valenti, lqng-term behaviour of hydraulic binders based on calcium sulfoaluminate and calcium sulfosilicate, Cement and Concrete Research.,25 (1), 113-126 (1995).

39. V. Kasselouri, P. Tsakiridis, Ch. Malami, B. Georgali, C. Alexandridou, A study on the hydration products of a non-expansive sulphoaluminate cement, Cement and Concrete Composites, 25 [17], 26-36 (1995). 40. C.W. Hargis, A. Telesca, P.J.M. Monteiro, Calcium sulfoaluminate (Ye'elimite) hydration in the presence of gypsum, calcite, and vaterite, Cement and Concrete Research. 65, 15-20 (2014). 